move the whole mass; and if the earth have a solid crnst only, with a fluid interior, the force will have to move only the crust, against the evanescent resistance of the fluid within during so short a space of time as it takes to produce precession. The resulting precessional motion will be different in the two cases; and therefore the actual amount of the precession which the earth's axis has (and which is a matter of observation) is a good test of the solidity or fluidity of the interior. This is Mr. Hopkins's method.

The force producing nutation is much smaller, even at its maximum, than the precessional force. Its effect, however, is precisely the same in this respect-that it depends upon the mass of the solid orust, and in no respect upon the friction of the fluid within it, which has not time to influence the nutation before the nutation is actually produced.

5. I do not here undertake to go into Mr. Hopkins's numerical calculations; I simply vindicate his method. I do not here consider what modification the elasticity of the solid materal of the earth may have upon his numerical results. I conceive that it would have no effect, if the disturbing force were constant and there were no nutation. For under the dragging influence (if I may so call it) of the constant precessional force, the solid material would be under a steady strain, and would communicate the effect of the force, continuously acting, from particle to particle of the solid part as if it were really rigid; and the resulting precessional motion would be greater or less as the mass of the solid part may be smaller or larger - that is, the solid crust thinner or thicker. But as the disturbing force is not constant, but variable, and there is constantly nutation of the axis as well as precession, the action above described will be somewhat modified; and the elasticity of the solid material may be expected to have some influence on the result. This influence, however, will be minute, as the part of the disturbing force which is variable and produces nutation is very much smaller, even at its maximum, than the precessional force. The consideration of this matter, however, has no bearing upon the validity or not of Mr. Hopkins's method, but simply upon the numerical value of his final result, not upon the question of the fluidity or solidity of the earth's mass.

6. It will appear then, I, think to your readers that the strictures of $M$. Delaunay upon this method, which the genius of $\mathbf{M r}$. Hopkins devised, betray an oversight of the real point upon which the success of his method depends, and that this method stands unimpaired.

\title{
ITOTICHS OF MEMOIRS.
}

I.-On the Discovere of a Fossil Shake, Prthon Eubotcus, Roemer, in the Tertiary Calcareous Slates of the Brown-coal formation of Kumi, in the Island of Eubœa. By Hurn Ferd. Roemirk, of Breslau.

[Abdruck a. d. Zeitschr. d. Deutschen geologischen Gesellschaft, Jahrg. 1870.]

GOSSIL snakes are exceedingly rare remains. Prof. Owen has H described four species of Palaophis and two species of 
Paleryx, from the London Clay, Middle and Lower Eocene of England, ${ }^{1}$ and the remains of a serpent Laophis crotaloides, Ag. discovered by Capt. Spratt, R.N., in a Tertiary formation at Salonica. ${ }^{2}$ We noticed the discovery, by Prof. O. C. Marsh, of Yale College, Ct., U.S., of a new gigantic fossil serpent, Dinophis grandis, from the Tertiary of New Jersey, last month (p. 377).

The description, therefore, of a comparatively well preserved, and clearly identified ophidian, from the Tertiary limestone (Kalkschiefer) of Kumi, in the Island of Euboea, by Prof. Roemer, of Breslau, is so important as to merit the attention of palæontologists.

The remains were found in a slab of limestone, 9in. in length by 5in. in breadth, which exhibits on its surface the vertebral column and ribs of an ophidian.

It was procured for the University Museum from the cabinet of the late Dr. Beinert, and is stated to have been obtained from the wall of the Brown-coal deposit of $\mathrm{Knmi}$, and is probably of Miocene Tertiary Age, like those from the Braunkohlen formation of Germany.

The portion of the skeleton preserved consists of part of the vertebral column, $9 \frac{1}{2}$ in. in length, and comprising 25 vertebræ with the ribs attached, also the greater part of the left ramus of the lower jaw, with eight of the teeth in situ. The specimen is so disposed upon the slab that about half the vertebro exhibit their dorsal, and hialf their ventral, aspect.

The vertebræo of the fossil snake correspond, in all important respects, with those of the living Python. When compared with those of Pythor bivittatus the dorsal processes are somewhat less pronounced, and the antero-lateral faces are somewhat produced. The form also of the vertebræ enabled the author to determine to what portion of the column of the snake these bones belonged. The vertebra of the anterior part of the back-bone of the living Python are provided with processes (hypapophyses), directed obliquely downwards and backwards, the length of which is equal to, or exceeds, the diameter of the body of the ,vertebra. The remaining vertebræ, down to the candal series, do not possess these inferior processes. In place of this they are provided with a small rounded protuberance, in which the ventral ridge terminates at the hinder end. Prof. Roemer detached the two most anterior vertebre of the fossil $P$ ython, but found no hypapophyses under them, but a small rounded prominence like that observed in the dorsal series of the living Python. This shows that the fossil vertebre in question belong to the middle part of the trunk. The uniformity of the size of the vertebræ also proves them to be from the central portion; for anteriorly and posteriorly they diminish in the living Pythons and Boas.

The ribs are only partially preserved, but 16 of the right side remain in situ; they are sabre-like in form, and correspond with those of the recent $P$. bivittatus already referred to. They are expanded at the proximal end, and are provided with an articulating face by which they are united to the corresponding articulating face of the

1 Pal. Soc. Lond. Mon. Ophidia, 1849-60.

Quart. Journ. Geol. Soc., Lond., vol. xiii., 1857, p. 196. 
protuberance (Diapophysial tubercle, Owen) on the side of the vertebral body. The thinnest part of the rib is at five-sixths of the entire length, and the last sixth becomes broader, and terminates bluntly.

It is interesting to find that in Miocene times various large tropical snakes had their habitat in Greece, and it adds another fact to $\mathbf{M}$. Gaudry's interesting discoveries of a tropical mammalian fauna in this ancient continent, of which but so small a part now remains.

\section{II.-Nww Amerioan Rmptibia.}

By Prof. J. D. Cope.

THEE fossil which Prof. Cope exhihited was the almost perfect 1 cranium of a Mosasauroid reptile, the Clidastes propython. $\mathbf{H e}_{\boldsymbol{e}}$ explained various peculiarities of its structure, as the moveable articulation of certain of the mandibular pieces on each other, the suspension of the os-quadratum at the extremity of a cylinder composed of the opisthotic, etc., and other peculiarities. He also explained from specimens, the characters of a large new Plesiosauroid from Kansas, discovered by Wm. E. Webb, of Topeka, which possessed deeply biconcave vertebræ, and anchylosed neural arches, with the zygapophyses directed after the manner usual among vertebrates. The former was thus shown to belong to the true Sauropterygia, and not to the Streptosauria, of which Elasmosaurus was type. Several distal caudals were anchylosed, without chevron bones, and of depressed form, while proximal caudals had anchylosed diapophyses and distinct chevron bones. The form was regarded as new, and called Polycotylus latipinnis, from the great relative stoutness of the paddle.

Prof. Cope also gave an account of the discovery, by Dr. Samuel Lockwood, of Keyport, of a fragment of a large Dinasaur, in the clay which underlies immediately the marls below the lower green sand bed in Monmouth County, New Jersey. The piece was the extremities of the tibia and fibula, with astragalo-calcaneum anchylosed to the former, in length about sixteen inches; distal width fourteen. The confluence of the first series of tarsal bones with each other, and with the tibia, he regarded as a most interesting peculiarity, and one only met with elsewhere in the reptile Compsognathus and in birds. He therefore referred the animal to the order Symphypoda, near to Compsognathus Wagn. The extremity of the fibula was free from, and received into, a cavity of the astragalo-calcaneum, and demonstrated what the author had already asserted, that the fibula of Iguanodon and Hedrosaurus had been inverted by their describers. The medullary cavity was filled with open cancellous tissue. The species, which was one half larger than the type specimen of Hadrosaurus Foulkii, he named Ornithotarsus immanis.

1 Proceeding American Phil. Soc., Vol. XI., p. 117. 
III.-Notion of a New Sproies of Gaviat from thi Eocent of NeW JERSEY, U.S.

By Prof. 0, C. Marse, of Yale College, Ct. ${ }^{1}$

GOME interesting reptilian remains have recently been obtained D from the Eocene Greensand of Shark River, Monmouth County, New Jersey, indicative of a new species of Gavial, considerably amaller than any crocodilian heretofore discovered. They were found together, and are evidently parts of the same skeleton. They consist of various fragments of the skull, and ten vertebræ. The coössification of the neural arches of the vertebre, and the almost entire obliteration of the sutures in some of them would imply that the individual, although dimjnutive, was nearly or quite mature.

The portions of the skull preserved indicate that the animal had an elongated muzzle, and that the upper posterior parts of the skull were of the gavial type. The temporal apertures were large and near together. The teeth were not obtained.

The vertebree are well preserved, and present marked characters. The articular oup is transwersely oval in the cervicals and anterior dorsals, and has its upper margin depressed in the posterior dorsals. The hypapophyses are simple and elongate. The neural canal of the cervical and anterior dorsal series is transverse and sub-rectangular in outline, and the floor unusually broad and flat. In the posterior dorsals, the canal, although still transverse, becomes less rectangular, with the broader portion above.

The species may prove to be generically identical with the one named by the writer Thecachampsa Squankensis, which is the only orocodilian hitherto found in the Eocene of New Jersey.

The genus Thecachampsa, however, as proposed by Prof. Cope, cannot yet be regarded as a valid one, since the concentric structure of the dentine on which it was founded ${ }^{2}$ is not a character of generic importance; for it occurs in various other crocodilians, and also in some Cetacea. The present remains are therefore provisionally placed in the genus Gavialis and the species called $G$. minor. The animal to which these remains belonged was quite slender and about six foet in length.

IV.-Rigcords of thix Gmologroal Survity of India. Vol. iii, Part 2. MaX, 1870.

The Contents of this number of the "Records" are-

1. Geology of Gwalior and its vicinity. By C. A. HАOKET.

7 HE area described is a low hilly district, comprising some alluvium. Crystalline rocks occupy a narrow strip of country, which is also traversed by numerous large quartz veins. But the more prominent rooks of the area belong to the Gwalior Series and the Upper Vindhyan. These two series are unconformable to each

1 From American Journal Science, Second Series, vol. 1., no. 148, p. 07.

- Procedings Philadolphia Acad. Nat. Sciences, 1867, p. 143. 
other, the former having been immensely denuded before the deposition of the latter.

The Gwalior Series is composed of quartzite, sandstone, limestone, jasper, and contemporaneous trap. It is divided into two groupsthe Par, and above it the Morar Group. Diorite is the form of trap which occurs in these beds, a variety in which the separate crystals of hornblende and felspar are visible to the naked eye. Magnetic iron is found in it.

The Vindhyan rocks occurring in the area were described by $\mathbf{M r}$. Mallet (see Grological Magazine, April, 1870, p. 171). Their age was pointed out as very uncertain, possibly Devonian. No conclusion can be drawn as to the exact place of the Gwalior Series in the Indian scale.

2. Note on the Slates at Chiteli, Kumaon. By Thmodone W. H. Hugres, F.G.S.-The author having been requested to report on the suitability of the slates for roofing purposes, accordingly visited the locality, where an experimental quarry had been opened. The slates dip at high angles, but they are not cleaved in a definite manner. Their general quality bears favourable comparison with other Indian specimens; but it is below the standard of typical Welsh slate. It differs from the latter in splitting along the planes of lamination, instead of the planes of cleavage. It is coarser in texture, and more siliceous. The slate is good enough for roofing purposes, it well withstands the action of the weather, and slabs less than a quarter of an inch in thickness, and much more than a square foot, superficial measurement, may be easily obtained.

3. Note on the Lead Vein near Chicoli, Raipur District. By W. T. Buanford, F.G.S.-The ore (galena) occurs in a well-marked vein, ehiefly composed of quartz, which traverses the metamorphic rocks. The vein also contains pink felspar, green and purple fluorspar. Slight but unmistakeable indications of the presence of copper were found. The width of the vein varies greatly; sometimes it is six feet, at others, nearly 30 feet. Altogether, Mr. Blanford thinks there is nothing in the appearances presented by the Chicoli Lode, inconsistent with the occurrence of a good vein of lead and copper ore below the surface. $\mathrm{He}_{e}$ adds, that it is the first instance of a distinct metallic Lode he has seen in India.

4. The Wardha River Coal-fields, Berar and Central Proninces. By Dr. OldfaM, F.R.S., etc.-These coal-fields have been previously noticed in the "Records," Vol. ii., Part 4, p. 94, but since that time great progress has been made in the detailed exploration of the field.

Thick beds of coal had been observed in the banks of the river Wardha, but their continuance inland could not be traced, owing mainly to thick coverings of clays. It was found necessary to maks borings, the resalts of a few were given in the previous report; records of the other borings, and the general results are now given. The inland extension of the coal-beds has been proved in many places, and their great and sudden variation in character is markedly indicated. In Wun district, to the West of Wardha, there is estimated to be about 70 square miles of country under which the thick 
coal may fairly be presumed to extend, and probably nowhere will it be found at a greater depth than 120 yards below the surface. The average thickness of coal established by the numerous trials may be taken as nearly 40 feet, but this includes some beds that would not be worth working, and probably 20 feet would represent the maximum thickness of workable coal. Taking these data, and making allowance for faults and disturbances, Dr. Oldham calculates that there is an available quantity of coal in East Berar equal to about 480,000,000 tons.

Passing into Chanda, the small area oocupied by coal, precisely the same as that in Berar, would probably yield about $78,000,000$ tons of workable coal.

5. Roport on the Coal at Korba, in the Bilaspur District. By W.T. Busnrord, F.G.S.-The coal is exposed in two places int the bed of the Hasdo river, just below Korba. The thickness was estimated, though' roughly, from its dip and length of outcrop, to be at least 90 feet, including bands of shale and inferior coal. In order to obtain a more correct idea of the quality of the coal, small pits were dug; these proved a minimum thickness of 50 feet of fair coal. Mr. Blanford points out the best places for borings in order to ascertain the extent of the seam, as sufficient data are not known to justify the opening of a coal mine. Both the quality and mode of occurrence of the coal are considered favourable, and indeed, to surpass that near Chanda.

\section{正耳VIFW.}

I.-Raport of the Rugby School Natural History Society for THE YeAR, 1869. Rugby: W. Billington, 1870, pp. 59.

WF have already called attention to the activity of this useful Society. The third report now issued shows it to have lost none of its vigour. Throughout the academical year meetings have woen held each fortuight, and masters and scholars alike have contributed; by papers and presentations, or exhibitions of nalural history specimens or apparatus, to render them very interesting. Of the many papers read but a few are printed. They suffice to show, however, that the salient features of recent scientific discovery are with little delay laid before the members, and not a few report the results of individual observation. Among these is a valuable paper by Mr. J. M. Wilson, on the Drifts, Gravels, and Alluvial Soils of kugby and its neighbourhood, describing some borings which he caused to be made, and the specimens obtained from them which he has deposited in the Arnold Library. "English Snakes and the Blindworm" is the title of a contribution by Mr. N. Masterman that is well worth reading. The author has studied the lives and habits of his pets, and speaks of them with an enthusiasm which is quite delightful. The botany of the neighbourhood has not been neglected, now localities are registered, and the variations in dates of flowering recorded. The mention of three other papers will suffice to show

vor. VIr, - NO, LXXV. 